\title{
The effect of dietary fiber level on milk fat concentration and fatty acid profile of cows fed diets containing low levels of polyunsaturated fatty acids ${ }^{1}$
}

\author{
O. AlZahal, M. M. Or-Rashid, S. L. Greenwood, M. S. Douglas, and B. W. McBride ${ }^{2}$ \\ Department of Animal and Poultry Science, University of Guelph, Guelph, Ontario, Canada, N1G 2W1
}

\begin{abstract}
The objective of this study was to investigate the effect of dietary fiber level on milk fat concentration, yield, and fatty acid (FA) profile of cows fed diets low in polyunsaturated fatty acid (PUFA). Six rumenfistulated Holstein dairy cows $(639 \pm 51 \mathrm{~kg}$ of body weight) were used in the study. Cows were randomly assigned to 1 of 2 dietary treatments, a high fiber (HF; $\%$ of dry matter, $40 \%$ corn silage, $27 \%$ alfalfa silage, $7 \%$ alfalfa hay, $18 \%$ protein supplement, $4 \%$ ground corn, and $4 \%$ wheat bran) or a low fiber (LF; $\%$ of dry matter, $31 \%$ corn silage, $20 \%$ alfalfa silage, $5 \%$ alfalfa hay, $15 \%$ protein supplement, $19 \%$ ground wheat, and $10 \%$ ground barley) total mixed ration. The diets contained similar levels of PUFA. The experiment was conducted over a period of $4 \mathrm{wk}$. Ruminal $\mathrm{pH}$ was continuously recorded and milk samples were collected 3 times a week. Milk yield and dry matter intake were recorded daily. The rumen fluid in cows receiving the LF diet was below $\mathrm{pH} 5.6$ for a longer duration than in cows receiving the HF diet (357 vs. $103 \mathrm{~min} / \mathrm{d}$ ). Neither diet nor diet by week interaction had an effect on milk yield $(\mathrm{kg} / \mathrm{d})$, milk fat concentration and yield, or milk protein concentration and yield. During wk 4, milk fat concentration and milk fat yield were high and not different between treatments $(4.30 \%$ and $1.36 \mathrm{~kg} / \mathrm{d}$ for the $\mathrm{HF}$ treatment and $4.31 \%$ and $1.33 \mathrm{~kg} / \mathrm{d}$ for the $\mathrm{LF}$ treatment, respectively). Cows receiving the LF diet had greater milk concentrations $(\mathrm{g} / 100 \mathrm{~g}$ of FA) of 7:0; 9:0; 10:0; 11:0; 12:0; 12:1; 13:0; 15:0; linoleic acid; FA $<\mathrm{C} 16$; and PUFA; and lower concentrations of iso 15:0; 18:0; trans-9 18:1; cis-9, trans-11 conjugated linoleic acid (CLA); trans-9, cis-12 18:2; 20:0; and cis-9 20:1 compared with cows receiving the HF diet. Milk concentrations (g/100 g of FA) of total trans 18:1; trans-10
\end{abstract}

\footnotetext{
Received June 20, 2008.

Accepted October 31, 2008

${ }^{1}$ The authors thank Laura Wright and the staff of the Elora Dairy Research Centre (University of Guelph, ON, Canada) for their technical assistance. We acknowledge the continued support received from the Ontario Ministry of Agriculture Food and Rural Affairs and the Natural Sciences and Engineering Research Council of Canada (B. W. McBride).

${ }^{2}$ Corresponding author: bmcbride@uoguelph.ca
}

18:1; trans-11 18:1; trans-10, cis-12 CLA, and trans-9, cis-11 CLA were not different between treatments. The study demonstrated that cows fed a diet low in fiber and low in PUFA may exhibit subacute ruminal acidosis and moderate changes to milk fatty acid profile but without concomitant milk fat depression. The changes in FA profile may be useful for the diagnosis of SARA even in the absence of milk fat depression.

Key words: dietary fiber, milk fat depression, polyunsaturated fatty acid, ruminal $\mathrm{pH}$

\section{INTRODUCTION}

The effect of physically effective fiber (peNDF) in the diet on ruminal $\mathrm{pH}$ in dairy cows has been extensively studied. Zebeli et al. (2008) summarized data from 45 published studies and demonstrated that ruminal $\mathrm{pH}$ was increased by increasing dietary peNDF up to $31 \%$ (DM basis), beyond which ruminal $\mathrm{pH}$ reached a plateau (daily mean ruminal $\mathrm{pH}$ 6.27). However, peNDF in that study explained only $50 \%$ of the variation in ruminal $\mathrm{pH}$. Additional dietary factors such as ruminal degradable starch from grain and DM intake level were also shown to affect ruminal $\mathrm{pH}$ despite the presence of apparently adequate levels of peNDF. For example, Zebeli et al. (2008) demonstrated that, at a fixed level of peNDF ( $31 \%$ of DM), increasing the dietary ruminal degradable starch from 14 to $22 \%$ and DMI from 20 to $25 \mathrm{~kg} / \mathrm{d}$ reduced ruminal $\mathrm{pH}$ significantly.

The effect of dietary factors and thus ruminal $\mathrm{pH}$ on milk fat (MF) is inconsistent. Some studies reported a reduction in MF with low ruminal $\mathrm{pH}$ (Gentile et al., 1986; Stone, 1999), whereas others showed no effect of $\mathrm{pH}$ on MF concentrations (Keunen et al., 2002; Krause and Oetzel, 2005; Rustomo et al., 2006). Additionally, Allen (1997) summarized the association between ruminal $\mathrm{pH}$ and MF percentage from 23 studies and concluded that ruminal $\mathrm{pH}$ explained only $39 \%$ of the variation in $\mathrm{MF}$ percentage. Bauman and Griinari (2001) defined 2 conditions for MF depression (MFD) to occur. The first was altering microbial process (i.e., low ruminal $\mathrm{pH}$ as result of low-fiber/high-grain diet) and the second was the presence of polyunsaturated fatty acids (PUFA) in the diet. They proposed the biohydrogenation theory 
to explain the MFD phenomenon, which states that under specific dietary conditions, intermediates resulting from altered ruminal biohydrogenation $(\mathbf{B H})$ act on the mammary gland inhibiting de novo synthesis of fatty acids (FA). Later studies identified conjugated linoleic acid (CLA) isomers that may be involved in MFD such as trans-10, cis-12 CLA (Baumgard et al., 2000), cis-10, trans-12 CLA (Sæbø et al., 2005), and trans-9, cis-11 CLA (Perfield et al., 2007).

The inconsistencies in the literature regarding the effect of low dietary fiber on MFD then could be explained, in part, by differences in dietary PUFA content; therefore, we hypothesize that diets low in fiber and rich in grains that induce a ruminal $\mathrm{pH}$ depression will not cause MFD provided that these diets are low in PUFA. The objective of this study was to investigate the effect of dietary fiber level on MF concentration, MF yield, and FA profile of cows fed low dietary PUFA.

\section{MATERIALS AND METHODS}

\section{Animals, Experimental Treatments, and Feeding}

Six rumen-fistulated, multiparous, lactating Holstein cows $(639 \pm 51 \mathrm{~kg}$ of BW, $140 \pm 49 \mathrm{DIM})$ were used in this study. The cows were housed in a tie-stall facility at Elora Dairy Research Centre (University of Guelph, Guelph, Ontario, Canada) and were cared for and handled in accordance with the Canadian Council on Animal Care regulations (CCAC, 1993). The University of Guelph Animal Care Committee approved their use for this experiment.

Cows were assigned randomly to 1 of 2 dietary treatments: high fiber $(\mathbf{H F})$ or low fiber $(\mathbf{L F})$. Treatment periods were of 4-wk duration. The diet was offered as a TMR at 0700 and $1300 \mathrm{~h}$ daily. The amount of feed was adjusted based on the previous week average of DMI to allow maximum orts of $5 \mathrm{~kg} / \mathrm{d}$. Ingredients and chemical analyses and FA profile of the experimental TMR are shown in Tables 1 and 2, respectively.

\section{Experimental Measures and Samples Analyses}

Ruminal $\mathrm{pH}$ was measured and recorded continuously every minute during the last $3 \mathrm{~d}$ of each experimental week using a $\mathrm{pH}$ recording system as described by AlZahal et al. (2007c). The $\mathrm{pH}$ electrodes were calibrated weekly using standard buffer solutions of $\mathrm{pH} 4.0$ and 7.0 (Fisher Scientific, Fairlawn, NJ).

Feed intake and milk yield were monitored daily throughout the experiment. Total mixed ration samples from each dietary treatment and ort samples from each individual animal were collected 3 times per week and frozen at $-20^{\circ} \mathrm{C}$ until analysis. The orts samples were pooled per cow per week proportionally to the amount of the orts. The TMR samples were pooled per week per treatment. Pooled TMR and orts samples were dried for $48 \mathrm{~h}$ in a forced-air oven to determine the DM content for that week. At the end of the experiment, dried TMR samples were ground through a 1-mm screen (Wiley mill, Arthur H. Thomas Co., Philadelphia, PA) and pooled by treatment across all weeks. Samples were analyzed at Agri-Food Laboratory (Guelph, Ontario, Canada) for DM, CP, ash, ether extract, lignin, ADF (AOAC, 1996), NDF (Mertens, 2002), soluble CP (Licitra et al., 1996), and starch concentration (Hall, 2000).

Cows were milked twice daily at 0500 and $1500 \mathrm{~h}$, and milk samples were collected in duplicate 3 times per week during morning and afternoon milking throughout the experiment. Milk samples for FA analysis were frozen immediately at $-20^{\circ} \mathrm{C}$ until analysis. Milk samples for component analysis were preserved with 2-bromo2-nitropropane-1-2-diol and stored at $4^{\circ} \mathrm{C}$. Every week, milk samples for components analysis were pooled by cow by day based on a constant proportion of 60:40 (a.m.:p.m., respectively) and then were pooled by week using equal proportions and submitted to Laboratory Services Division (Guelph, Ontario, Canada) for analysis using a near-infrared analyzer (Foss System 4000, Foss Electric, Hillerød, Denmark).

Diets were formulated to meet or exceed nutrients requirements using the Cornell-Penn-Miner system (CPM-Dairy, v 3.0.8, Cornell Univeristy, Ithaca, NY; University of Pennsylvania, Kennett Square, PA; William H. Miner Agricultural Research Institute, Chazy, NY). To ensure a consistent supply of nutrients, experimental TMR compositions were adjusted to address any changes in moisture contents of the forages. Estimation of starch fermentation rate $(\% / h)$ for a given TMR was conducted using default values (CPM-Dairy) of the ingredients' starch concentrations and starch fermentation rates. Diets did not contain a monensin premix nor did cows receive monensin boluses during current lactation.

\section{Milk FA Analysis}

Milk samples collected for FA analysis during wk 4 were thawed at $37^{\circ} \mathrm{C}$ and pooled per week as explained above. Lipids for FA analysis were extracted from pooled milk samples according to Bligh and Dyer (1959) with minor modifications. A 50 - to $75-\mu \mathrm{L}$ milk sample (based on fat concentration) was mixed with water to total $1 \mathrm{~mL}$, and $2.5 \mathrm{~mL}$ of methanol and 1.25 $\mathrm{mL}$ of chloroform were added in a $15-\mathrm{mL}$ screw-top culture tube with Teflon lining. The contents of the culture tube were vortexed and kept for 30 min at room 
Table 1. Ingredient composition and chemical analyses of experimental high-fiber or low-fiber TMR

\begin{tabular}{|c|c|c|}
\hline Item & High fiber & Low fiber \\
\hline \multicolumn{3}{|l|}{ Ingredient/TMR, $\%$ of DM } \\
\hline Corn silage & 40.4 & 30.6 \\
\hline Alfalfa silage & 26.9 & 20.4 \\
\hline Mixed hay & 6.9 & 5.2 \\
\hline Corn (ground) & 4.1 & 0.0 \\
\hline Wheat bran & 4.2 & 0.0 \\
\hline Wheat (ground) & 0.0 & 18.9 \\
\hline Barley (ground) & 0.0 & 9.5 \\
\hline Protein supplement ${ }^{1}$ & 17.7 & 15.4 \\
\hline \multicolumn{3}{|l|}{ Chemical composition } \\
\hline \multirow[t]{2}{*}{$\mathrm{DM}, \%$} & 36.3 & 42.6 \\
\hline & \multicolumn{2}{|c|}{$\%$ of $\mathrm{DM}$} \\
\hline $\mathrm{CP}(\mathrm{N} \times 6.25)$ & 18.2 & 17.1 \\
\hline Soluble protein & 6.0 & 3.9 \\
\hline $\mathrm{ADF}$ & 27.0 & 21.0 \\
\hline $\mathrm{NDF}$ & 40.0 & 32.7 \\
\hline Lignin & 4.5 & 3.2 \\
\hline Ether extract & 2.4 & 2.0 \\
\hline Ash & 7.8 & 6.4 \\
\hline $\mathrm{NFC}^{2}$ & 31.6 & 41.8 \\
\hline Starch $^{3}$ & 12.6 & 24.1 \\
\hline $\mathrm{NE}_{\mathrm{L}}{ }^{4} \mathrm{Mcal} / \mathrm{kg}$ & 1.50 & 1.66 \\
\hline Est. starch fermentation rate, ${ }^{5} \% / \mathrm{h}$ & 25.6 & 34.5 \\
\hline
\end{tabular}

${ }^{1}$ Contained (\% of DM): 48\%-soybean meal, 24.8; high-protein corn gluten meal, 19.8; canola meal, 10.1; roasted soybean (whole), 10.4; fish meal (herring), 5.1; beet pulp, 1.3; calcium carbonate (limestone), 3.9; dicalcium phosphate, 4.9; soybean hulls (ground), 5.9; sodium bicarbonate, 4.4; salt, 2.8; molasses (in pelleter), 1.8; urea, 2.8; magnesium oxide, 1.0; Organic Ruminant Micro Premix (Floradale Feed Mill Ltd., Floradale, ON, Canada), 0.7; sulfur flour (99.5\%), 0.4; Rovimix Biotin (H-2, DSM Nutritional Products, Inc., Parsippany, NJ), 0.02 .

${ }^{2} \mathrm{NFC}=100-(\mathrm{NDF}+\mathrm{CP}+$ ether extract + ash $)$.

${ }^{3}$ Analyzed according to Hall (2000).

${ }^{4}$ Estimated using CPM-Dairy (v 3.0.8, Cornell University, Ithaca, NY; University of Pennsylvania, Kennett Square, PA; William H. Miner Agricultural Research Institute, Chazy, NY) using the chemical analysis of feed ingredients.

${ }^{5}$ Estimated fermentation rate of dietary starch calculated from the CPM-Dairy default values of starch content of dietary ingredients and the ingredients' fermentation rates.

temperature. Additionally, $60.7 \mu \mathrm{L}$ of $\mathrm{HCl}(3 N)$ was added and vortexed. Subsequently, $1.25 \mathrm{~mL}$ of chloroform and $1.25 \mathrm{~mL}$ of water were added, vortexed, and centrifuged. The lower chloroform phase containing lipid was transferred into a $15-\mathrm{mL}$ culture tube by using 2 Pasteur pipettes (one inserted into the other). Another $1.25 \mathrm{~mL}$ of chloroform was added to the lipidcontaining solution and centrifuged. The contents were then transferred into a 4-mL vial passing through a Pasteur pipet column containing a glass wool plug [washed with chloroform and methanol (1:1) and dried] and a $2-\mathrm{cm}$ bed of anhydrous $\mathrm{Na}_{2} \mathrm{SO}_{4}$ to absorb any moisture within the sample. The contents of the tube were dried under an $\mathrm{N}_{2}$ stream at room temperature, and then 3 to 4 drops of benzene were added and vortexed. Then, $1.7 \mathrm{~mL}$ of hexane and $40 \mu \mathrm{L}$ of methyl acetate were added into the vial one after the other and mixed. One hundred microliters of Na-methoxide (0.5 $M$ solution in methanol, Sigma-Aldrich, St. Louis, MO) was added for methylation. The vial was heated at $50^{\circ} \mathrm{C}$ for $15 \mathrm{~min}$ and then cooled down at $-20^{\circ} \mathrm{C}$ for $10 \mathrm{~min}$.
After cooling, $60 \mu \mathrm{L}$ of oxalic acid (10\% solution in ether) was added to the vial and vortexed and then 0.5 $\mathrm{mL}$ of water was added to the vial and centrifuged to settle a Na-oxalate precipitate. One milliliter of the upper portion containing FA methyl ester (FAME) was transferred to a $2-\mathrm{mL}$ vial.

The analysis of FAME was performed using a GLC (Agilent 6890N, Agilent Technologies, Palo Alto, CA) equipped with a split/splitless injector, a flameionization detector at $250^{\circ} \mathrm{C}$ (Agilent Technologies), and a capillary column (CP-Sil 88 column; $100 \mathrm{~m}, 0.25$ $\mathrm{mm}, 0.2 \mu \mathrm{m}$ of film thickness, Varian Inc., Mississauga, Ontario, Canada). Agilent Chemstation software (Rev. B.01.01) was used for data analysis. Hydrogen was used as carrier gas at a constant flow rate of $1 \mathrm{~mL} / \mathrm{min}$. The temperature of the GLC oven was set to $45^{\circ} \mathrm{C}$ for 4 min, increased at $13^{\circ} \mathrm{C} / \mathrm{min}$ to $175^{\circ} \mathrm{C}$, held for $27 \mathrm{~min}$, increased by $4^{\circ} \mathrm{C} / \mathrm{min}$ to a final temperature of $215^{\circ} \mathrm{C}$, and held for $35 \mathrm{~min}$. A $1-\mu \mathrm{L}$ sample containing 1 to 2 $\mu \mathrm{g}$ was injected at splitless mode to determine FAME presence at low concentration. Peaks were identified by 
Table 2. Fatty acid profile (g/100 g of fatty acids) of experimental high-fiber or low-fiber TMR

\begin{tabular}{lcc}
\hline Item & High fiber & Low fiber \\
\hline $10: 0$ & 0.025 & 0.023 \\
$12: 0$ & 0.235 & 0.253 \\
$14: 0$ & 0.380 & 0.446 \\
$15: 0$ & 0.112 & 0.110 \\
$16: 0$ & 16.6 & 18.6 \\
$16: 1$ cis- & 0.265 & 0.306 \\
$16: 1$ cis-9 & 0.492 & 0.473 \\
$17: 0$ & 0.147 & 0.162 \\
$18: 0$ & 4.55 & 4.69 \\
$18: 1$ cis-9 & 19.6 & 19.5 \\
$18: 1$ cis-11 & 2.14 & 1.97 \\
$18: 1$ cis-12 & 0.181 & 0.364 \\
$18: 1$ cis-13 & 0.090 & 0.102 \\
$18: 1$ cis-14 & 0.511 & 0.499 \\
$18: 2$ n-6 & 39.1 & 38.5 \\
$18: 3$ n-3 & 9.05 & 7.53 \\
$19: 0$ & 0.126 & 0.175 \\
$20: 0$ & 0.625 & 0.525 \\
$20: 1$ cis-11 & 0.770 & 0.833 \\
$20: 2$ n-6 & 0.045 & 0.045 \\
$20: 4$ n-6 & 0.020 & 0.015 \\
$20: 5$ n-3 & 0.102 & 0.120 \\
$22: 0$ & 0.516 & 0.488 \\
$22: 6$ n-3 & 0.123 & 0.088 \\
$23: 0$ & 0.147 & 0.138 \\
$24: 0$ & 0.376 & 0.401 \\
PUFA ${ }^{1}$ (total) & 48.4 & 48.9 \\
Unidentified & 3.6 & 3.7 \\
\hline
\end{tabular}

${ }^{1}$ Polyunsaturated fatty acids.

comparison of retention times with a GLC reference FAME standard (GLC \#463, \#UC-59-M, 21:0, 23:0, and 26:0; Nu-Chek Prep Inc., Elysian, MN). The trans-11, cis-15 18:2 isomer was identified by cross-referencing with previously published isomeric profiles reported for MF using cis-9, cis-12 18:2 as a landmark isomer (Ulberth and Henninger, 1994; Precht and Molkentin, 1997). Individual isomers of 18:1 FA were determined as follows: the temperature of the GLC oven was maintained at $45^{\circ} \mathrm{C}$ for $4 \mathrm{~min}$, increased to $167^{\circ} \mathrm{C}$ at a rate of $13^{\circ} \mathrm{C} / \mathrm{min}$ and held for $40 \mathrm{~min}$, and increased again at the rate of $4^{\circ} \mathrm{C} / \mathrm{min}$ to a final temperature of $218^{\circ} \mathrm{C}$ and held for 23 min. Separation of trans and cis octadecenoic acids was incomplete, but the chromatography allowed the major isomers of interest to be resolved. The trans-6, trans-7, and trans-8 18:1 isomers and the trans-13 and trans-14 18:1 isomers remained unresolved as single peaks. Individual trans isomers were identified by cross-referencing with previously published isomeric profiles reported for MF (Precht and Molkentin, 1997; Shingfield et al., 2003; Loor et al., 2004) using trans-11 18:1 as a landmark isomer. Fatty acid composition was expressed as grams per one hundred grams of total FA.

Feed FA analysis was conducted on dried, ground, and pooled HF and LF TMR samples as mentioned above.

\section{Statistical Analysis}

Statistical analysis was conducted on weekly averages of DMI, milk yield, milk components, and ruminal $\mathrm{pH}$ parameters. The MIXED procedure (SAS Institute, 2004) was followed using the model $Y_{i j}=\mu+D_{i}+W_{j}$ $+(\mathrm{D} \times \mathrm{W})_{\mathrm{ij}}+\mathrm{e}_{\mathrm{ij}}$, where $\mathrm{Y}_{\mathrm{ij}}=$ the dependent variable, $\mu=$ overall mean, $\mathrm{D}_{\mathrm{i}}=$ effect of $\operatorname{diet}(\mathrm{i}=1,2), \mathrm{W}_{\mathrm{j}}=$ effect of week $(\mathrm{j}=1, . ., 4),(\mathrm{D} \times \mathrm{W})_{\mathrm{ij}}=$ effect of diet $\times$ week $\left({ }_{\mathrm{ij}}=1, \ldots, 8\right)$, and $\mathrm{e}_{\mathrm{ij}}=$ random residual error.

The effects of week and diet were considered as fixed effects. Week of experiment was used as a repeated measurement, with cow within dietary treatment as the subject. Orthogonal polynomial contrast was used to describe the linear, quadratic, and cubic terms of week effect and week by diet interaction. For each analyzed variable, cow was subjected to 5 covariance structures: compound symmetry, heterogeneous compound symmetry, autoregressive order 1 , heterogeneous autoregressive order 1, and unconstructured structure. The covariance structure that gave the smallest Bayesian information criterion was used (Littell et al., 1996). Milk FA profile analysis was conducted on pooled milk samples collected during wk 4; therefore, the statistical analysis on FA data was conducted using the same statistical model excluding the week effect.

\section{RESULTS AND DISCUSSION}

The objectives of the diet formulation were to maintain milk production in both treatments, and to provide diets with low PUFA concentration (Tables 1 and 2). The HF diet contained a high fiber content to eliminate the risk of SARA, whereas the LF diet contained low fiber and greater amount of rapidly fermentable carbohydrate (wheat and barley) than the HF diet to induce ruminal $\mathrm{pH}$ depression. The estimated total dietary starch fermentation rate was $34.6 \% / \mathrm{h}$ for the $\mathrm{LF}$ diet compared with $25.6 \% / \mathrm{h}$ for the HF diet (Table 1). The chemical analyses of the experimental TMR agreed closely with formulation targets.

\section{Induction of SARA}

The amount of time that rumen fluid $\mathrm{pH}$ was below $5.6,5.8$, or 6 was greater in cows receiving the LF diet than in cows receiving the HF diet (Table 3). Rumen fluid $\mathrm{pH}$ for cows receiving the LF diet was below 5.6, 5.8 , and 6.0 on average for 357,650 , and $975 \mathrm{~min} / \mathrm{d}$ compared with 103, 253, and $523 \mathrm{~min} / \mathrm{d}$ for cows receiving the HF diet, respectively. Based on previous nutritionally induced SARA studies (Gozho et al., 2005; AlZahal et al., 2007a), SARA was defined as existing when rumen fluid $\mathrm{pH}$ below 5.6 occurred for at least 3 
$\mathrm{h} / \mathrm{d}$. Therefore, cows receiving the LF diet were considered to have SARA. There was no effect $(P>0.05)$ of week by diet interaction on time below $\mathrm{pH} 5.6,5.8$, and 6.0 , which indicated that the difference in ruminal $\mathrm{pH}$ between the 2 treatments was consistent throughout the experiment. Although the LF diet seemed sufficient in fiber, the provision of highly fermentable carbohydrate (ground wheat and barley) led to a significant depression in ruminal fluid $\mathrm{pH}$. Therefore, the source and processing of starch should be taken into consideration when formulating diets for lactating cows. Estimating the total diet starch fermentation rate could provide a useful measure for assessing the risk of SARA.

\section{DMI and Milk Yield and Components}

There was no change in the DMI of cows receiving the HF diet, whereas the DMI of the cows receiving the LF diet increased from wk 1 to 4 (23.7 vs. $25.0 \mathrm{~kg} / \mathrm{d}$; linear week by diet, $P<0.05$; Table 3$)$. Fiber level had no effect $(P>0.05)$ of DMI or milk yield. The HF diet contained an extremely large amount of fiber to eliminate the risk of SARA; on the other hand, the LF diet contained low fiber and large amount of ground wheat and barley to ensure that SARA occurred. Nonetheless, both diets were expected to reduce DMI and milk yield, the HF diet due to a rumen fill condition (Allen, 2000) and the LF diet due to SARA (Nocek, 1997), which may explain, in part, the lack of treatment effect on DMI and milk yield observed in the present experiment.

Results indicated that there was no effect of diet on milk components $(P>0.05$, Table 3). Additionally, there was no linear or quadratic time (week) by diet interaction effect on any of milk components $(P>0.05$; Table 3), which indicated that there were no differences in milk components over time between treatments by wk 4 (Table 3 ). There were significant quadratic and cubic effects of time (fluctuation in both treatments) on MF concentration and MF yield $(\mathrm{kg} / \mathrm{d})$, protein yield $(\mathrm{kg} / \mathrm{d})$, and lactose concentration and yield $(\mathrm{kg} / \mathrm{d})$. These responses likely reflected the changes in milk yield.

In the present experiment, linoleic acid (LA) intake was approximately $175 \mathrm{~g} / \mathrm{d}$ (Table 3) and reflected the product of DMI and LA concentration in the diet. This very low level of LA intake could have contributed to the overall high MF percentage $(4.3 \pm 0.4)$. A previous study (AlZahal et al., 2008) reported a lower MF concentration ranging from 3.76 to 3.14 in response to daily intake of LA ranging from 208 to $341 \mathrm{~g} / \mathrm{d}$. Milk yield levels observed in the present study were similar to the previous study (AlZahal et al., 2008); therefore, it is believed that the greater level of MF observed in

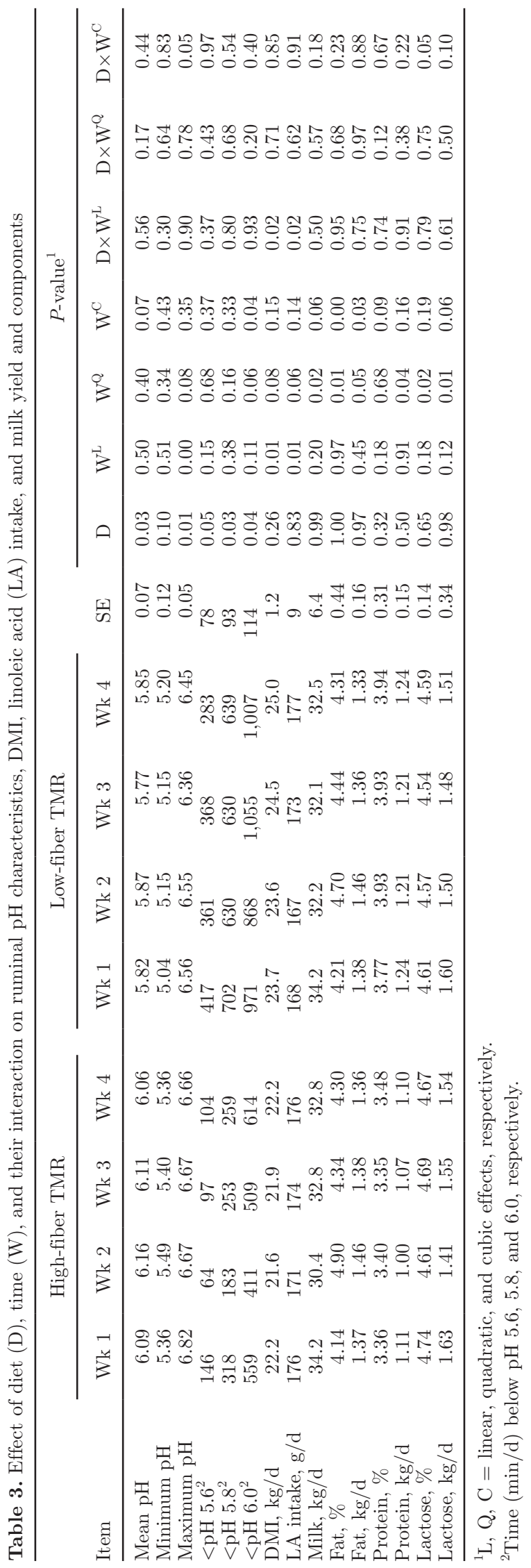


the present study compared with the previous (AlZahal et al., 2008) was mainly due to the lower LA intake.

The inclusion of wheat and barley in the LF instead of corn, beside the induction of SARA, contributed to minimizing the amount of LA encountered by feeding a large amount of corn. For example, if the wheat and barley were replaced by corn in the LF diet, the total dietary LA would have increased by $85 \mathrm{~g} / \mathrm{d}$ (from 177 to $300 \mathrm{~g} / \mathrm{d}$, according to CPM-Dairy). This level of LA is believed to cause moderate MFD; however, this depression would be magnified when a low fiber diet is fed (ruminal pH was depressed; AlZahal et al., 2007b). Additionally, the nutritional model used to induce SARA by replacing $25 \%$ of TMR by wheat and barley, without supplemental PUFA, showed no MFD (Keunen et al., 2002). However, supplemental wheat and barley caused a significant MFD when soybean oil was infused ruminally, which emphasized that MFD is related to LA intake and that the severity of this MFD is related to fiber level in the diet (Bauman and Griinari, 2001). There is little information in the literature on the relationship between LA intake (g/d) and MF concentration. Therefore, further research is needed to examine this relationship with factors that influence $\mathrm{BH}$ within the rumen.

\section{Milk Fatty Acids}

Milk FA profile during the last week (wk 4) of the experiment is presented in Tables 4, 5, and 6. Cows receiving the LF diet had greater $(P<0.05)$ milk concentrations $(\mathrm{g} / 100 \mathrm{~g}$ of FA) of 7:0; 9:0; 10:0; 11:0; 12:0; 12:1; 13:0; 15:0; FA $<$ C16; LA; and lower $(P<$ $0.05)$ concentrations of iso 15:0; 18:0; trans-9 18:1; cis9, trans-11 CLA; trans-9, cis-12 18:2; 20:0; and cis-9 20:1 compared with cows receiving the HF diet. The concentration ( $\mathrm{g} / 100 \mathrm{~g}$ of $\mathrm{FA})$ of trans $18: 1$; trans-10 18:1; trans-11 18:1; trans-10, cis-12 CLA; and trans-9, cis-11 CLA were not different between treatments.

Roy et al. (2006) demonstrated that the concentration of cis-9, trans-11 CLA declined when lipid was supplemented to moderate- and high-starch diets and that the decline in cis-9, trans-11 CLA was associated with an increase in MF concentration (g/100 g of FA) of trans-10 18:1. Those changes in MF profile likely reflected a shift in the pathway of ruminal BH (Roy et al., 2006). Additionally, Van Nevel and Demeyer (1996) showed with in vitro studies that ruminal lipolysis was reduced when $\mathrm{pH}$ dropped below $\mathrm{pH}$ 6.0. The reduction was reduced by $50 \%$ when $\mathrm{pH}$ was maintained at 5.5 , whereas $\mathrm{BH}$ was less sensitive to $\mathrm{pH}$ and was reduced when $\mathrm{pH}$ was lower than 5.5. Because only free FA can be biohydrogenated, Van Nevel and Demeyer (1996) suggested that the inhibition of $\mathrm{BH}$ observed with highconcentrate diets was due to an inhibition of lipolysis.
In the current study, there was an increase (18.6\%) in milk concentration of LA for cows receiving the LF diet, and this increase occurred in conjunction with reductions in the concentrations of cis-9, trans-11 CLA $(24.3 \%)$ and $18: 0(24.3 \%)$ in agreement with the previously mentioned studies. Nonetheless, the lack of effect on milk concentration of trans-10 18:1 and trans-10, cis-12 CLA was likely due to the presence of low dietary PUFA.

Odd- and branched-chain FA (BCFA) are significant components of bacterial and protozoal FA, 16.5 and 11.0 (g/100 g), respectively (Or-Rashid et al., 2007). The contents of these FA in the milk have been used as markers for the estimation of microbial protein flow from the rumen (Vlaeminck et al., 2005). Moreover, the efficiency of transfer from the duodenum to the milk was found to be similar to that of C18:3. However, actual milk yields of $\mathrm{C} 15: 0,17: 0$, and iso 17:0 have exceeded the duodenal flow of these FA, suggesting the possibility of some de novo synthesis within animal tissue (Dewhurst et al., 2007) or transfer to the mammary gland of these fatty acids mobilized from adipose reserves.

In the current study, cows receiving the LF treatment had a greater concentration (g/100 g of FA) of total FA $<\mathrm{C} 16$ than those receiving the HF treatment (29.0 vs. 24.7 , respectively; Table 4). This difference was mainly because of an increase in even-straight-chain FA (22.05 vs. 25.36, $P=0.013$ ) and in part to an increase in odd-chain FA andBCFA (2.7 vs. $3.6, P=0.007)$. The observed treatment differences in milk FA $<\mathrm{C} 16$ between treatments were likely due to the differences in provision of fermentable carbohydrate, which leads to differences in rumen production of acetate, a precursor of mammary de novo fatty acid production.

A recent study (Craninx et al., 2007) suggested that BCFA and odd-straight-chain FA concentrations in the milk could be used to diagnose acute acidosis and SARA in dairy cattle. Their results showed that rumen $\mathrm{pH}$ was positively correlated with iso 14:0 and iso 15:0 (BCFA) and negatively correlated with 15:0 and 17:0 plus cis-9 17:1 FA concentrations. In the current study, cows receiving the LF treatment (SARA cows) had lower iso-15:0 concentration (g/100 g of total milk FA; $P$ $<0.05)$ and numerically lower anteiso-13:0 $(P=0.098)$ than cows receiving the HF treatment, whereas iso13:0, iso-14:0, and anteiso-15:0 concentrations ( $\mathrm{g} / 100 \mathrm{~g}$ of total milk FA, $P>0.05$ ) were not different between treatments. Additionally, the LF treatment had greater concentrations (g/100 $\mathrm{g}$ of milk FA) of 7:0, 9:0, 11:0, 13:0, and 15:0 than the HF treatment (Table 4), but had no effect on the concentration of 17:0. The total concentration of odd-straight-chain FA (7:0 to 17:0, $\mathrm{g} / 100 \mathrm{~g}$ of milk FA) was $3.3 \pm 0.1$ and $2.3 \pm 0.1$ for 
Table 4. Milk fatty acid (FA) profile (g/100 g of FA) in response to high-fiber and low-fiber TMR during wk 4 of the experiment

\begin{tabular}{|c|c|c|c|c|}
\hline \multirow[b]{2}{*}{ Item } & \multicolumn{2}{|c|}{ TMR } & \multirow[b]{2}{*}{$\mathrm{SE}$} & \multirow[b]{2}{*}{$P$-value } \\
\hline & High fiber & Low fiber & & \\
\hline $6: 0$ & 1.85 & 1.86 & 0.104 & 0.95 \\
\hline $7: 0$ & 0.023 & 0.057 & 0.003 & 0.002 \\
\hline $8: 0$ & 1.081 & 1.152 & 0.119 & 0.69 \\
\hline $9: 0$ & 0.020 & 0.056 & 0.004 & 0.003 \\
\hline 10:0 & 2.73 & 3.43 & 0.08 & 0.003 \\
\hline 11:0 & 0.343 & 0.549 & 0.026 & 0.005 \\
\hline $12: 0$ & 3.37 & 4.53 & 0.06 & 0.000 \\
\hline $12: 1$ & 0.098 & 0.216 & 0.013 & 0.003 \\
\hline $13: 0$ iso & 0.026 & 0.019 & 0.002 & 0.14 \\
\hline 13:0 anteiso & 0.091 & 0.131 & 0.013 & 0.10 \\
\hline $13: 0$ & 0.100 & 0.166 & 0.014 & 0.031 \\
\hline $14: 0$ iso & 0.134 & 0.093 & 0.015 & 0.13 \\
\hline $14: 0$ & 11.91 & 12.95 & 0.36 & 0.11 \\
\hline $14: 1$ cis -9 & 1.010 & 1.216 & 0.138 & 0.35 \\
\hline 15:0 iso & 0.217 & 0.163 & 0.009 & 0.012 \\
\hline 15:0 anteiso & 0.433 & 0.410 & 0.013 & 0.27 \\
\hline $15: 0$ & 1.31 & 1.96 & 0.07 & 0.003 \\
\hline 16:0 iso & 0.328 & 0.247 & 0.051 & 0.32 \\
\hline 16:0 & 34.92 & 35.59 & 1.56 & 0.78 \\
\hline $16: 1$ cis-9 & 1.51 & 1.73 & 0.36 & 0.69 \\
\hline $16: 1$ trans -9 & 0.067 & 0.065 & 0.005 & 0.67 \\
\hline 17:0 iso & 0.275 & 0.276 & 0.010 & 0.98 \\
\hline 17:0 anteiso & 0.520 & 0.498 & 0.018 & 0.44 \\
\hline $17: 0$ & 0.480 & 0.522 & 0.029 & 0.36 \\
\hline 18:0 & 10.33 & 7.82 & 0.51 & 0.025 \\
\hline $18: 1 \mathrm{cis}$ & 19.28 & 17.14 & 1.10 & 0.24 \\
\hline $18: 1$ trans & 3.37 & 2.91 & 0.26 & 0.28 \\
\hline $18: 1$ total & 22.65 & 20.05 & 1.32 & 0.24 \\
\hline $18: 2^{1}$ & 2.07 & 2.40 & 0.07 & 0.026 \\
\hline CLA $^{2}$ & 0.53 & 0.44 & 0.04 & 0.18 \\
\hline $18: 3$ n-3 & 0.397 & 0.403 & 0.012 & 0.73 \\
\hline $18: 3$ n-6 & 0.019 & 0.024 & 0.002 & 0.21 \\
\hline 19:0 & 0.027 & 0.020 & 0.004 & 0.27 \\
\hline $20: 0$ & 0.184 & 0.131 & 0.010 & 0.018 \\
\hline $20: 1$ cis -9 & 0.163 & 0.131 & 0.007 & 0.028 \\
\hline $20: 1$ cis-11 & 0.084 & 0.080 & 0.003 & 0.38 \\
\hline $20: 2$ n- 6 & 0.021 & 0.023 & 0.001 & 0.30 \\
\hline $20: 3$ n-3 & 0.007 & 0.006 & 0.001 & 0.32 \\
\hline $20: 3$ n-6 & 0.101 & 0.092 & 0.012 & 0.58 \\
\hline $20: 4$ n-3 & 0.040 & 0.027 & 0.005 & 0.13 \\
\hline $20: 4$ n-6 & 0.106 & 0.115 & 0.006 & 0.35 \\
\hline $20: 5$ n-3 & 0.044 & 0.042 & 0.003 & 0.68 \\
\hline $22: 0$ & 0.079 & 0.052 & 0.009 & 0.10 \\
\hline $22: 1$ cis-13 & 0.005 & 0.005 & 0.000 & 0.59 \\
\hline $22: 2 \mathrm{n}-6$ & 0.018 & 0.013 & 0.002 & 0.13 \\
\hline $22: 4$ n- 6 & 0.020 & 0.021 & 0.004 & 0.76 \\
\hline $22: 5 \mathrm{n}-3$ & 0.056 & 0.057 & 0.004 & 0.80 \\
\hline $22: 6$ n-3 & 0.058 & 0.053 & 0.005 & 0.52 \\
\hline 23:0 & 0.034 & 0.024 & 0.005 & 0.19 \\
\hline 24:0 & 0.038 & 0.024 & 0.007 & 0.20 \\
\hline $24: 1$ cis-15 & 0.005 & 0.005 & 0.001 & 0.56 \\
\hline $26: 0$ & 0.020 & 0.024 & 0.007 & 0.75 \\
\hline \multicolumn{5}{|l|}{ Summation by source ${ }^{3}$} \\
\hline$<\mathrm{C} 16$ & 24.75 & 28.97 & 0.54 & 0.005 \\
\hline $16: 0$ and $16: 1$ & 36.83 & 37.63 & 1.84 & 0.77 \\
\hline$>\mathrm{C} 16$ & 38.42 & 33.41 & 1.85 & 0.13 \\
\hline Total saturates & 70.92 & 72.79 & 1.05 & 0.274 \\
\hline Total monounsaturated FA & 25.59 & 23.50 & 1.07 & 0.239 \\
\hline Total polyunsaturated FA & 3.49 & 3.72 & 0.03 & 0.008 \\
\hline
\end{tabular}

${ }^{1}$ Sum of 18:2 FA excluding conjugated linoleic acid (CLA).

${ }^{2}$ Total CLA isomers.

${ }^{3} \mathrm{FA}<16: 0$ originated from de novo synthesis, FA $>16: 0$ were preformed FA taken up by the mammary gland, and 16:0 and 16:1 FA came from both de novo and preformed sources. 
Table 5. Milk concentration of 18:1 fatty acids (g/100 g of fatty acids) in response to high-fiber and low-fiber TMR during wk 4 of the experiment

\begin{tabular}{lcccc}
\hline & \multicolumn{3}{c}{ TMR } & \\
\cline { 2 - 3 } Item & High fiber & Low fiber & SE & P-value \\
\hline Cis-9 & 17.61 & 15.48 & 0.97 & 0.19 \\
Cis-11 & 1.33 & 1.30 & 0.13 & 0.89 \\
Cis-12 & 0.306 & 0.327 & 0.028 & 0.64 \\
Cis-13 & 0.032 & 0.029 & 0.007 & 0.80 \\
Trans-4 & 0.013 & 0.014 & 0.002 & 0.86 \\
Trans-5 & 0.013 & 0.010 & 0.002 & 0.46 \\
Trans-6+7+8 & 0.250 & 0.235 & 0.013 & 0.46 \\
Trans-9 & 0.457 & 0.358 & 0.013 & 0.006 \\
Trans-10 & 0.43 & 0.48 & 0.05 & 0.56 \\
Trans-11 & 1.10 & 0.83 & 0.09 & 0.11 \\
Trans-12 & 0.420 & 0.356 & 0.035 & 0.26 \\
Trans-13+14 & 0.52 & 0.47 & 0.06 & 0.56 \\
Trans-16+cis-14 & 0.169 & 0.167 & 0.020 & 0.95 \\
\hline
\end{tabular}

${ }^{1}$ Unresolved peak.

the LF and HF treatments $(P<0.002)$, respectively. The mechanism explaining the changes in BCFA is not well understood. However, recent studies demonstrated that some bacteria such as Listeria monocytogenes have the ability to manipulate their membrane's odd-chain BCFA as a protective measure against environmental insults such as temperature (Annous et al., 1997) and pH (Giotis et al., 2007). For example, the amounts of odd-chain BCFA present in the membrane of L. monocytogenes were reduced by the reduction in $\mathrm{pH}$ and by the increase in environmental temperature. In conclusion, the increase in odd-straight-chain FA and (or) the decrease in odd-chain BCFA may have the potential to diagnose SARA. More investigations are needed to determine the mechanism(s) thereof.

Milk concentrations ( $\mathrm{g} / 100 \mathrm{~g}$ of FA) of CLA isomers that inhibit MF synthesis such as trans-10, cis-12 (Baumgard et al., 2000); cis-10, trans-12 CLA (Sæbø et al., 2005); and trans-9, cis-11 CLA (Perfield et al., 2007) were low, and MF percentage and yield did not change across diets. The association between trans-10
18:1 and MFD was established quantitatively (Bauman and Griinari, 2003; Shingfield et al., 2006). However, a recent study (Lock et al., 2007) demonstrated that trans-10 18:1 does not cause MFD but it is a significant marker of an impaired ruminal $\mathrm{BH}$.

Future research on MFD should use a spectrum of dietary fiber/grain and PUFA levels that are typical to lactation diets; such data could be used to construct a nutritional model to predict the occurrence of MFD and associated milk FA profile.

\section{CONCLUSIONS}

This study demonstrated that a diet low in fiber and PUFA could cause SARA without concomitant MFD. The milk concentrations of CLA isomers known to inhibit de novo synthesis of fatty acids in the mammary gland were lower than those causing MFD. Additionally, the study showed that SARA might be diagnosed using the milk FA profile even in the absence of MFD.

Table 6. Milk concentration of 18:2 fatty acids ( $\mathrm{g} / 100 \mathrm{~g}$ of fatty acids) in response to high-fiber and low-fiber TMR during wk 4 of the experiment

\begin{tabular}{|c|c|c|c|c|}
\hline \multirow[b]{2}{*}{ Item } & \multicolumn{2}{|c|}{ TMR } & \multirow[b]{2}{*}{$\mathrm{SE}$} & \multirow[b]{2}{*}{$P$-value } \\
\hline & High fiber & Low fiber & & \\
\hline \multicolumn{5}{|l|}{ Nonconjugated } \\
\hline Cis- 9, cis-12 & 1.97 & 2.33 & 0.07 & 0.02 \\
\hline Trans-9, cis-12 & 0.064 & 0.039 & 0.004 & 0.01 \\
\hline Trans-11, cis-15 & 0.035 & 0.025 & 0.006 & 0.29 \\
\hline \multicolumn{5}{|l|}{ Conjugated } \\
\hline Cis- 9 , trans- 11 & 0.45 & 0.34 & 0.03 & 0.05 \\
\hline Trans-9, cis-11 & 0.028 & 0.028 & 0.003 & 0.98 \\
\hline Trans-10, cis-12 & 0.013 & 0.012 & 0.001 & 0.53 \\
\hline Trans -11, trans -13 & 0.018 & 0.030 & 0.010 & 0.43 \\
\hline Trans, trans ${ }^{1}$ & 0.028 & 0.028 & 0.003 & 0.99 \\
\hline
\end{tabular}

${ }^{1}$ Unresolved peak of trans-10, trans-12+trans-9, trans-11 conjugated linoleic acid. 


\section{REFERENCES}

Allen, M. S. 1997. Relationship between fermentation acid production in the rumen and the requirement for physically effective fiber. J. Dairy Sci. 80:1447-1462.

Allen, M. S. 2000. Effect of diet on short-term regulation of feed intake by lactating dairy cattle. J. Dairy Sci. 83:1598-1624.

AlZahal, O., E. Kebreab, J. France, and B. W. McBride. 2007a. A mathematical approach to predict biological values from rumen pH measurements. J. Dairy Sci. 90:3777-3785.

AlZahal, O., N. E. Odongo, M. M. Or-Rashid, T. Mutsvangwa, T. F. Duffield, R. Bagg, P. Dick, G. Vessie, and B. W. McBride. 2008. Effects of monensin and dietary soybean oil on milk fat percentage and milk fatty acid profile in lactating dairy cows. J. Dairy Sci. 91:1166-1174.

AlZahal, O., M. Or-Rashid, S. L. Greenwood, M. S. Douglas, and B. W. McBride. 2007b. Subacute ruminal acidosis increases milk fat depression with diets supplemented with polyunsaturated fatty acids. J. Dairy Sci. 90(Suppl. 1):561. (Abstr.)

AlZahal, O., B. Rustomo, N. E. Odongo, T. F. Duffield, and B. W McBride. 2007c. A system for continuous recording of ruminal $\mathrm{pH}$ in cattle. J. Anim. Sci. 85:213-217.

Annous, B. A., L. A. Becker, D. O. Bayles, D. P. Labeda, and B. J. Wilkinson. 1997. Critical role of anteiso-C15:0 FA in the growth of Listeria monocytogenes at low temperatures. Appl. Environ. Microbiol. 63:3887-3894.

AOAC. 1996. Official Methods of Analysis. 16th ed. Association of Official Analytical Chemists, Arlington, VA.

Bauman, D. E., and J. M. Griinari. 2001. Regulation and nutritional manipulation of milk fat: Low-fat milk syndrome. Livest. Prod. Sci. $70: 15-29$

Bauman, D. E., and J. M. Griinari. 2003. Nutritional regulation of milk fat synthesis. Annu. Rev. Nutr. 23:203-227.

Baumgard, L. H., B. A. Corl, D. A. Dwyer, A. Sæbø, and D. E. Bauman. 2000. Identification of the conjugated linoleic acid isomer that inhibit milk fat synthesis. Am. J. Physiol. 278:R179-R184.

Bligh, E. G., and W. J. Dyer. 1959. A rapid method of total lipid extraction and purification. Can. J. Biochem. Physiol. 37:911917.

CCAC (Canadian Council on Animal Care). 1993. Guide to the Care and Use of Experimental Animals. Vol. 1. E. D. Olfert, B. M. Cross, and A. A. McWilliam, ed. CCAC, Ottawa, Ontario, Canada.

Craninx, M., A. Beeckman, H. Van. Laar, J. Martin-Tereso, and V. Fievez. 2007. Diagnosis of acidosis in dairy cattle using milk fatty acid profiles. J. Anim. Sci. 85(Suppl. 1):560. (Abstr.)

Dewhurst, R. J., J. M. Moorby, B. Vlaeminck, and V. Fievez. 2007. Apparent recovery of duodenal odd- and branched-chain fatty acids in milk of dairy cows. J. Dairy Sci. 90:1775-1780.

Gentile, G., S. Cinotti, G. Ferri, and P. Famigli-Bergamini. 1986 Nutritional acidosis and technological characteristics of milk in high producing dairy cows. Page 823 in Proc. 14th World Congr. Diseases Cattle. P. J. Harigan and M. L. Monaghan, ed. Dublin, Ireland.

Giotis, E. S., D. A. McDowell, I. S. Blair, and B. J. Wilkinson. 2007. Role of branched-chain fatty acids in $\mathrm{pH}$ stress tolerance in Listeria monocytogenes. Appl. Environ. Microbiol. 73:997-1001.

Gozho, G. N., J. C. Plaizier, D. O. Krause, A. D. Kennedy, and K. M. Wittenberg. 2005. Subacute ruminal acidosis induces ruminal lipopolysaccharide release and triggers an inflammatory response. J. Dairy Sci. 88:1399-1403.

Hall, M. B. 2000. Starch gelatinization and hydrolysis method. Pages 29-38 in Neutral Detergent Soluble Carbohydrates, Nutritional Relevance and Analysis-A Laboratory Manual. Dept. Animal Science, Univ. Florida, Gainesville.

Keunen, J. E., J. C. Plaizier, I. Kyriazakis, T. F. Duffield, T. M Widowski, M. I. Lindinger, and B. W. McBride. 2002. Effects of a subacute ruminal acidosis model on the diet selection of dairy cows. J. Dairy Sci. 85:3304-3313.

Krause, K. M., and G. R. Oetzel. 2005. Inducing subacute ruminal acidosis in lactating dairy cows. J. Dairy Sci. 88:3633-3639.
Licitra, G., T. M. Hernandez, and P. J. Van Soest. 1996. Standardization of procedures for nitrogen fractionation of ruminant feeds. Anim. Feed Sci. Technol. 57:347-358.

Littell, R. C., G. A. Milliken, W. W. Stroup, and R. D. Wolfinger. 1996. SAS system for mixed models. SAS Institute Inc., Cary, NC.

Lock, A. L., C. Tyburczy, D. A. Dwyer, K. J. Karvatine, F. Destaillats, Z. Mouloungui, L. Candy, and D. E. Bauman. 2007. Trans-10 octadecenoic acid does not reduce milk fat synthesis in dairy cows. J. Nutr. 137:71-76.

Loor, J. J., K. Ueda, A. Ferlay, Y. Chilliard, and M. Doreau. 2004. Biohydrogenation, duodenal flow, and intestinal digestibility of trans fatty acids and conjugated linoleic acids in response to dietary forage:concentrate ratio and linseed oil in dairy cows. J. Dairy Sci. 87:2472-2485.

Mertens, D. R. 2002. Gravimetric determination of amylase-treated neutral detergent fiber in feeds with refluxing in beakers or crucibles: Collaborative study. J. AOAC 85:1217-1240.

Nocek, J. E. 1997. Bovine acidosis: Implications on laminitis. J. Dairy Sci. 80:1005-1028.

Or-Rashid, M. M., N. E. Odongo, and B. W. McBride. 2007. Fatty acid composition of ruminal bacteria and protozoa, with emphasis on conjugated linoleic acid, vacccenic acid, and odd-chain and branched-chain fatty acids. J. Anim. Sci. 85:1228-1234.

Perfield, J. W. II, A. L. Lock, J. M. Griinari, A. Sæbø, P. Delmonte D. A. Dwyer, and D. E. Bauman. 2007. Trans-9, cis-11 conjugated linoleic acid reduces milk fat synthesis in lactating dairy cows. J. Dairy Sci. 90:2211-2218.

Precht, D., and J. Molkentin. 1997. Trans-geometric and positional isomers of linoleic acid including conjugated linoleic acid (CLA) in German milk and vegetables fats. Lipids 99:319-326.

Roy, A., K. Ferlay, K. J. Shingfield, and Y. Chilliard. 2006. Examination of the persistency of milk fatty acid composition responses to plant oils in cows given different basal diets, with particular emphasis on trans-C18:1 fatty acids and isomers of conjugated linoleic acid. Anim. Sci. 82:479-492.

Rustomo, B., O. AlZahal, J. P. Cant, M. Z. Fan, T. F. Duffield, N. E. Odongo, and B. W. McBride. 2006. Acidogenic value of feeds. II. Effects of rumen acid load from feeds on dry mater intake, ruminal $\mathrm{pH}$, fiber degradability, and milk production in the lactating cow. Can. J. Anim. Sci. 86:119-126.

Sæbø, A., P. Sæbø, J. M. Griinari, and K. J. Shingfield. 2005. Effect of abomasal infusion of geometric isomers of 10, 12 conjugated linoleic acid on milk fat synthesis in dairy cows. Lipids 40:823-832.

SAS Institute. 2004. SAS/STAT Users Guide. Release 9.1. SAS Inst Inc., Cary, NC.

Shingfield, K. J., S. Ahvenjarvi, V. Toivonen, A. Arola, K. V. V. Nurmela, P. Huhtanen, and J. M. Griinari. 2003. Effect of fish oil on biohydrogenation of fatty acids and milk fatty acid content in cows. Anim. Sci. 77:165-179.

Shingfield, K. J., C. K. Reynolds, G. Hervas, J. M. Griinari, A. S. Grandison, and D. E. Beever. 2006. Examination of the persistency of milk fatty acid composition response to fish oil and sunflower oil in the diet of dairy cows. J. Dairy Sci. 89:714-732.

Stone, W. C. 1999. The effect of subclinical acidosis on milk components. Pages 40-46 in Cornell Nutrition Conference for Feed Manufacturers Cornell Univ., Ithaca, NY.

Ulberth, F., and M. Henninger. 1994. Quantitation of trans fatty acids in milk fat using spectroscopic and chromatographic methods. J. Dairy Res. 61:517-527.

Van Nevel, C. J., and D. I. Demeyer. 1996. Influence of pH on lipolysis and biohydrogenation of soybean oil by rumen contents in vitro. Reprod. Nutr. Dev. 36:53-63.

Vlaeminck, B., C. Dufour, A. M. van Vuuren, A. R. J. Cabrita, R. J. Dewhurst, D. Demeyer, and V. Fievez. 2005. Use of odd and branched-chain fatty acids in rumen contents and milk as a potential microbial marker. J. Dairy Sci. 88:1031-1042.

Zebeli, Q.. J. Dijkstra, M. Tafaji, H. Steingass, B. N. Ametaj, and W. Drochner. 2008. Modeling the adequacy of dietary fiber in dairy cows based on the responses of ruminal $\mathrm{pH}$ and milk fat production to composition of the diet. J. Dairy Sci. 91:2046-2066. 